\title{
Chemical Composition and Antimicrobial Effectiveness of Ocimum gratissimum L. Essential Oil Against Multidrug-Resistant Isolates of Staphylococcus aureus and Escherichia coli
}

\author{
Ramaiana Soares Melo 1,+ $\mathbb{D}$, Águida Maria Albuquerque Azevedo ${ }^{1,+}$, \\ Antônio Mateus Gomes Pereira ${ }^{1}$, Renan Rhonalty Rocha ${ }^{2}$, Rafaela Mesquita Bastos Cavalcante ${ }^{2}$, \\ Maria Nágila Carneiro Matos ${ }^{2}$, Pedro Henrique Ribeiro Lopes ${ }^{3}$, Geovany Amorim Gomes ${ }^{3}$, \\ Tigressa Helena Soares Rodrigues ${ }^{3}$, Hélcio Silva dos Santos ${ }^{3}{ }^{\mathbb{D}}$, Izabelly Linhares Ponte ${ }^{4}$, \\ Renata Albuquerque Costa ${ }^{1}$, Gabriel Sousa Brito ${ }^{5}$, Francisco Eduardo Aragão Catunda Júnior ${ }^{5}$ \\ and Victor Alves Carneiro 1,2,*iD \\ 1 Center of Bioprospection and Experimentation Molecular Applied (NUBEM), University Center \\ INTA-UNINTA, Sobral, Ceará 62050-100, Brazil; ramaiana_soares@hotmail.com (R.S.M.); \\ aguidamaria07@hotmail.com (Á.M.A.A.); mathewsgomes20@gmail.com (A.M.G.P.); \\ renata.albuq@gmail.com (R.A.C.) \\ 2 Laboratory of Biofilms and Antimicrobial Agents, Federal University of Ceará, Sobral, \\ Ceará 62042-280, Brazil; renanrocha38@gmail.com (R.R.R.); rafaelabastos.ufc@gmail.com (R.M.B.C.); \\ nagilacarneirobio@gmail.com (M.N.C.M.) \\ 3 Center of Exact Sciences and Technology, State University Vale do Acaraú, Sobral, Ceará 62040-370, Brazil; \\ hlopes2906@gmail.com (P.H.R.L.); pesquisadorgeo@yahoo.com.br (G.A.G.); \\ thelenasr@yahoo.com.br (T.H.S.R.); helciodossantos@gmail.com (H.S.d.S.) \\ 4 Pharmaceutical Coordinator of the Laboratory of Clinical Analysis of Santa Casa de Misericórdia de Sobral, \\ Sobral, Ceará 62010-550, Brazil; izabelly.ponte@gmail.com \\ 5 Center for Exact, Natural and Technological Sciences, State University of the Tocantina Region of Maranhão, \\ Imperatriz, Maranhão 65901-480, Brazil; gasobri0@gmail.com (G.S.B.); cearajr@gmail.com (F.E.A.C.J.) \\ * Correspondence: viktorcarneiro@gmail.com \\ + These authors contributed equally to this work.
}

Academic Editor: Daniela Rigano

Received: 6 September 2019; Accepted: 21 October 2019; Published: 26 October 2019

\begin{abstract}
The study investigated the antimicrobial activity of the essential oil extract of Ocimum gratissimum L. (EOOG) against multiresistant microorganisms in planktonic and biofilm form. Hydrodistillation was used to obtain the EOOG, and the analysis of chemical composition was done by gas chromatography coupled with mass spectrometry (GC/MS) and flame ionization detection (GC/FID). EOOG biological activity was verified against isolates of Staphylococcus aureus and Escherichia coli, using four strains for each species. The antibacterial action of EOOG was determined by disk diffusion, microdilution (MIC/MBC), growth curve under sub-MIC exposure, and the combinatorial activity with ciprofloxacin (CIP) and oxacillin (OXA) were determined by checkerboard assay. The EOOG antibiofilm action was performed against the established biofilm and analyzed by crystal violet, colony-forming unit count, and SEM analyses. EOOG yielded $1.66 \% w / w$, with eugenol as the major component (74.83\%). The MIC was $1000 \mu \mathrm{g} / \mathrm{mL}$ for the most tested strains. The growth curve showed a lag phase delay for both species, mainly S. aureus, and reduced the growth level of E. coli by half. The combination of EOOG with OXA and CIP led to an additive action for S. aureus. A significant reduction in biofilm biomass and cell viability was verified for S. aureus and E. coli. In conclusion, EOOG has relevant potential as a natural alternative to treat infections caused by multiresistant strains.
\end{abstract}


Keywords: antimicrobial activity; multiresistant microorganisms; ciprofloxacin; oxacillin; MDR bacteria; antibiofilm activity

\section{Introduction}

The rise of infections caused by multidrug-resistant (MDR) bacteria has become a worrying public health problem [1]. The occurrence of these strains is frequently related to strong selective pressure caused by indiscriminate and inadequate use of antibiotics in hospitals [2]. However, this is not a problem restricted to a nosocomial environment, as it can also be related to infections caused by foodborne pathogens [3]. In addition, another important issue is the ability of several bacteria to form a complex multicellular structure, called biofilms [4]. These tridimensional communities are built mainly by bacterial cells embedded into extracellular polysaccharides secreted by themselves [5], and this arrangement reduces the effectiveness of antimicrobial agents [6,7]. Thus, antibiotic resistance reduces the number of therapeutic options and causes an increase in hospitalization costs/time of patients, thus increasing the morbimortality rates [8].

As an alternative therapeutic source, essential oils (EOs) extracted from plants are qualified as an important biotechnological product to be explored for pharmaceuticals and food companies [9-12]. EOs are constituted by volatile organic products of various classes, such as aldehydes, terpenes, and phenolic compounds, synthesized by a secondary metabolism from different parts of plants [13]. Many studies have documented EOs to be effective antimicrobial agents against several pathogens [14-16]. Usually, this EO effect is closely related to the capability of permeabilizing and/or destroying membrane integrity, leading to the leakage of intracellular substances [17-19]. Moreover, since the last decade, the antibiofilm activity of EOs has been widely explored and reported in the literature [20-23].

O. gratissimum L. (EOOG), or clove basil, belongs to the Lamiaceae family, and it is commonly found in Africa, Asia, and South America [24]. This species is included among the 71 plants described in the National List of Medicinal Plants of Interest to the Unified Health System (RENISUS), created in 2009 in Brazil [25]. The use of leaf infusion has already been reported in folk medicine to treat fever, flu, and kidney problems [26]. Other reports have shown that the chemical composition of EOOG depends on the climate zone and soil type wherein the species is cultivated [27], and this feature can influence biological activity, since the major constituents can be altered [28]. Among the biological applications of EOOG, the antimicrobial properties have been studied separately or associated with conventional antibiotics, reestablishing the sensitivity of MDR bacteria [29-31]. Therefore, the aim of this study was to characterize the chemical constitution of EOOG extracted from dried leaves and explore in vitro the antibacterial and antibiofilm activity against $S$. aureus from clinical samples and E. coli isolates from fresh tilapia fillets commercialized in the retail trade of Sobral, Brazil, both of which having multiresistance phenotypes.

\section{Results}

\subsection{Extraction and Chemical Composition of the EOOG}

The dried leaves of O. gratissimum L. submitted to hydrodistillation in a Clevenger apparatus showed an EO yield of $1.66 \%(w / w)$. The chemical composition of the EOOG and their respective Kovats indices (KIs) are listed in Table 1. 
Table 1. Chemical composition from the essential oil (EO) of the Ocimum gratissimum L. (EOOG) leaves.

\begin{tabular}{|c|c|c|c|c|c|}
\hline Peak & Compounds ${ }^{a}$ & Chemical Class & $\mathrm{KIL}^{\mathrm{b}}$ & $\mathrm{KIC}^{\mathrm{c}}$ & $\%$ \\
\hline 1 & $\alpha$-Pinene & $\mathrm{HM}^{\mathrm{d}}$ & 939 & 943 & 0.08 \\
\hline 2 & Sabinene & HM & 975 & 982 & 0.17 \\
\hline 3 & $\beta$-Pinene & $\mathrm{HM}$ & 979 & 986 & 0.43 \\
\hline 4 & Myrcene & $\mathrm{HM}$ & 990 & 995 & 0.14 \\
\hline 5 & 1,8-Cineole & $\mathrm{OM}^{\mathrm{e}}$ & 1031 & 1040 & 15.16 \\
\hline 6 & (E)- $\beta$-Ocimene & $\mathrm{HM}$ & 1050 & 1053 & 0.10 \\
\hline 7 & Linalool & $\mathrm{OM}$ & 1096 & 1103 & 0.34 \\
\hline 8 & $\delta$-Terpineol & $\mathrm{OM}$ & 1166 & 1174 & 0.12 \\
\hline 9 & Terpinen-4-ol & $\mathrm{OM}$ & 1177 & 1184 & 0.16 \\
\hline 10 & $\alpha$-Terpineol & $\mathrm{OM}$ & 1188 & 1196 & 0.31 \\
\hline 11 & Eugenol & $\mathrm{PH}^{\mathrm{f}}$ & 1359 & 1365 & 74.83 \\
\hline 12 & (E)-Caryophyllene & HS ${ }^{g}$ & 1419 & 1427 & 2.20 \\
\hline 13 & $\alpha$-Humulene & HS & 1454 & 1461 & 0.32 \\
\hline 14 & $\gamma$-Muurolene & HS & 1479 & 1488 & 0.51 \\
\hline 15 & $\beta$-Selinene & HS & 1490 & 1493 & 2.82 \\
\hline 16 & $\alpha$-Selinene & HS & 1498 & 1501 & 0.85 \\
\hline 17 & 7-Epi- $\alpha$-selinene & HS & 1522 & 1525 & 0.26 \\
\hline 18 & Spathulenol & $\mathrm{OS}^{\mathrm{h}}$ & 1578 & 1584 & 0.07 \\
\hline 19 & $\begin{array}{c}\text { Caryophyllene } \\
\text { oxide }\end{array}$ & OS & 1583 & 1590 & 0.55 \\
\hline & Total & & & & 99.42 \\
\hline
\end{tabular}

a Compounds ordered by their elution from an HP-5MS column. ${ }^{\mathrm{b}}$ Kovats indices from the literature [32]. ${ }^{\mathrm{c}}$ Kovats indices calculated against n-alkanes $\left(\mathrm{C}_{9}-\mathrm{C}_{30}\right)$ on an HP-5MS column. ${ }^{\mathrm{d}}$ Hydrocarbon monoterpenes. ${ }^{\mathrm{e}}$ Oxygenated monoterpenes. ${ }^{\mathrm{f}}$ Phenylpropanoid. ${ }^{\mathrm{g}}$ Hydrocarbon sesquiterpenes. ${ }^{\mathrm{h}}$ Oxygenated sesquiterpenes.

Analysis by gas chromatography coupled with mass spectrometry (GC/MS) and flame ionization detection (GC/FID) resulted in the identification of 19 compounds in the sample, representing $99.42 \%$ of the constituents. The most abundant volatile component was eugenol $(74.83 \%)$, followed by 1,8-cineole (15.16\%) (Figure 1). However, several classes of chemical compounds were found, mainly phenylpropanoid $(74.83 \%)$, oxygenated monoterpenes $(16.09 \%)$, hydrocarbon sesquiterpenes $(6.96 \%)$, and minor amounts of hydrocarbon monoterpenes $(0.92 \%)$ and oxygenated sesquiterpenes $(0.62 \%)$.<smiles>C=CCc1ccc(O)c(OC)c1</smiles>

Eugenol<smiles>CC12CCC(CC1)C(C)(C)O2</smiles>

1,8 - Cineole

Figure 1. Chemical structures of the major constituents from the EO of Ocimum gratissimum L. (EOOG) dry leaves.

\subsection{Antibacterial Activity}

The results demonstrated that EOOG has significant antimicrobial activity against all tested strains. The EO had a large inhibition zone diameter (IZD) against $S$. aureus cells, among which, 5B and 2B had higher $(20 \mathrm{~mm})$ and lower $(14 \mathrm{~mm})$ IZD, respectively. However, this promising effect decreased slightly against $E$. coli cells, and the IZD values were kept around $12-13 \mathrm{~mm}$. According to the microdilution method, the minimum inhibitory concentration (MIC) of EOOG was observed at $1000 \mu \mathrm{g} / \mathrm{mL}$ indistinctly for $S$. aureus and E. coli cells, with the exception of $5 \mathrm{~B}$, which had twice the amount, $2000 \mu \mathrm{g} / \mathrm{mL}$. It is important that salient E. coli strains had the same bacteriostatic and 
bactericidal concentration levels (MIC and MBC), at $1000 \mu \mathrm{g} / \mathrm{mL}$. Therefore, S. aureus strains presented double the quantity $(2000 \mu \mathrm{g} / \mathrm{mL})$ necessary to eliminate the cells (2B, 5B, and 7B). All IZDs, as well as MIC and MBC values of EOOG, are shown in Table 2.

Table 2. Antibacterial activity of the EOOG against S. aureus and E. coli strains by the paper disk diffusion test and the microdilution method.

\begin{tabular}{|c|c|c|c|}
\hline Staphylococcus aureus & $\operatorname{IZD}(\mathrm{mm})^{1}$ & $\operatorname{MIC}(\mu \mathrm{g} / \mathrm{mL})^{2}$ & $\operatorname{MBC}(\mu \mathrm{g} / \mathrm{mL})^{3}$ \\
\hline ATCC 6538 & 17 & 1000 & 1000 \\
\hline $2 \mathrm{~B}$ & 14 & 1000 & 2000 \\
\hline $5 B$ & 20 & 2000 & 2000 \\
\hline $7 \mathrm{~B}$ & 15 & 1000 & 2000 \\
\hline \multicolumn{4}{|l|}{ Escherichia coli } \\
\hline ATCC 11303 & 12 & 1000 & 1000 \\
\hline P12 & 13 & 1000 & 1000 \\
\hline P25 & 12 & 1000 & 1000 \\
\hline P36 & 13 & 1000 & 1000 \\
\hline
\end{tabular}

Notes: IZD ${ }^{1}$ : Inhibition zones diameter using $6 \mathrm{~mm}$ disks. MIC ${ }^{2}$ : Minimum inhibitory concentration. $\mathrm{MBC}^{3}$ : Minimum bactericidal concentration.

\subsection{Bacterial Growth Curve}

The majority of strains in the control group, media broth only, clearly presented different growth, adaptation (lag), exponential (log), and stationary phases, as expected. However, the presence of EOOG (1/2 MIC) interfered with the performance of these microorganisms during curve development, as shown in Figure 2.

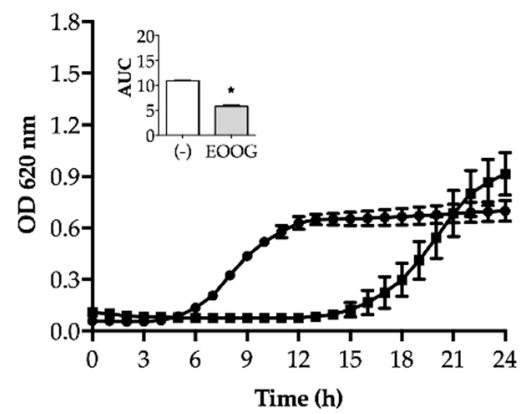

(a)

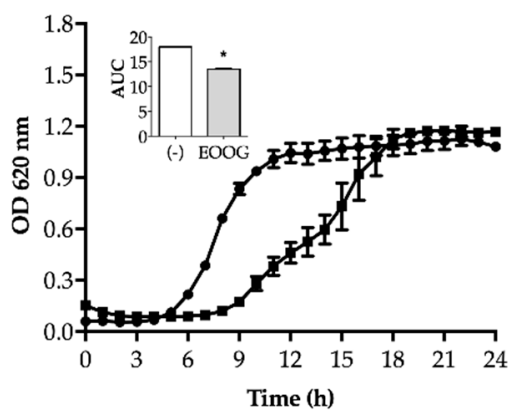

(c)

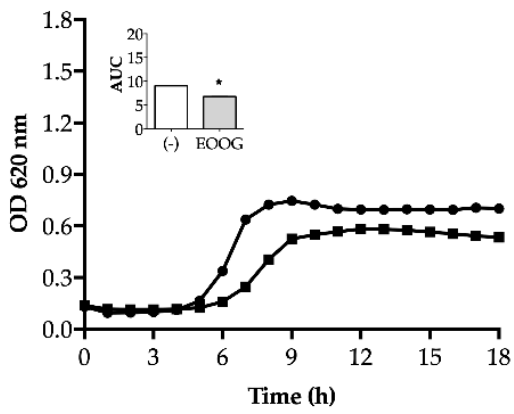

(b)

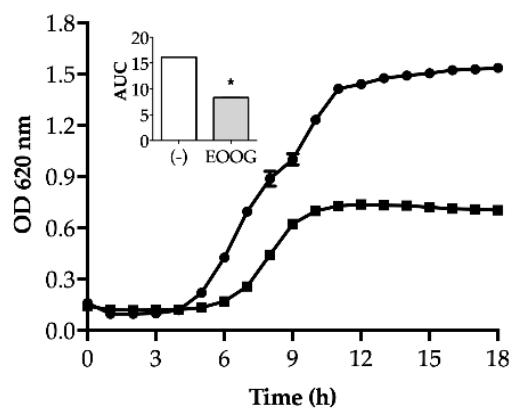

(d)

Figure 2. Cont. 


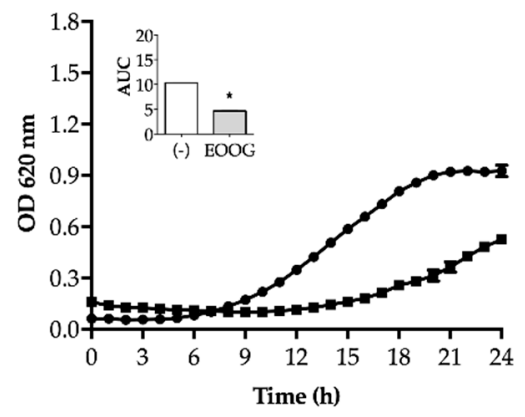

(e)

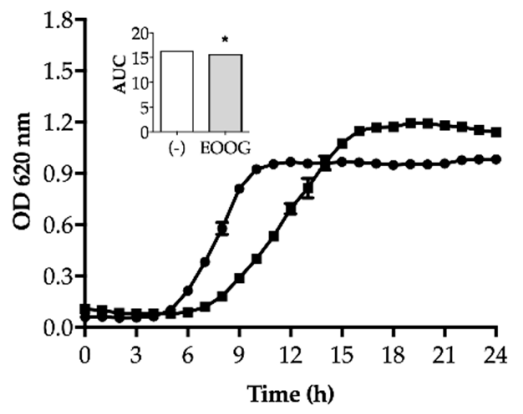

(g)

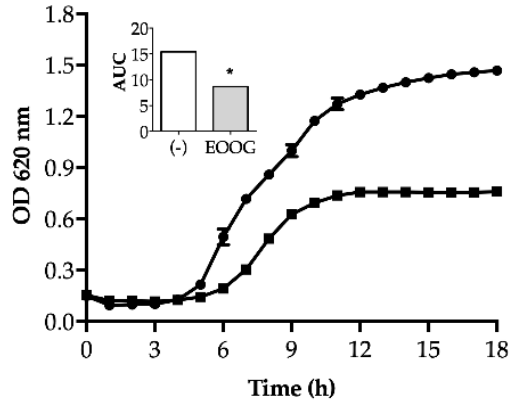

(f)

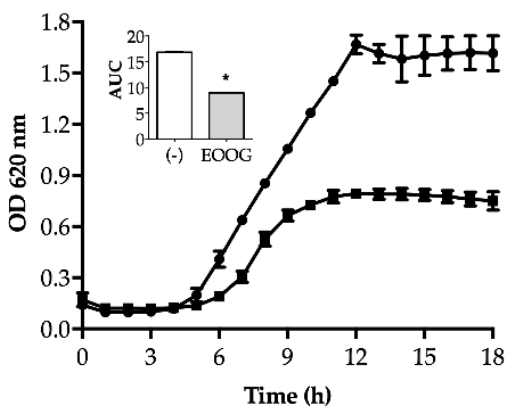

(h)

Figure 2. Effect of EOOG (1/2 MIC) on the bacterial growth curve (line graph) of S. aureus (a) ATCC 6538, (c) 2B, (e) 5B, and (g) 7B and of E. coli, (b) ATCC 11303, (d) P12, (f) P25, and (h) P36. The growth level of the EOOG-treated ( $\square /$ grey bar) and -untreated $(\bullet /$ white bar) cells was quantified by the area under the curve (AUC). * Statistically different by ANOVA $(p<0.01)$ compared to the control group.

S. aureus cells left the lag phase after $5 \mathrm{~h}$ of incubation, which was followed by a $5 \mathrm{~h}$ exponential phase before reaching the stationary stage, which consisted of $12 \mathrm{~h}$ of development. The presence of EOOG delayed the beginning of the multiplication step, prolonging the lag phase. However, at the end of growth (24 h), the optical density (OD) was similar between the control and the EOOG group. However, S. aureus 5B reached the stationary phase only after $21 \mathrm{~h}$ of incubation. The EOOG reduced the bacterial growth to $50 \%$ of the control OD at the end of the curve (Figure 2).

All E. coli displayed three growth phases after $18 \mathrm{~h}$. Except for the ATCC strain, they presented a short lag and an expressive log growth, reaching a high level (>1,500 UA) of absorbance at the end of the curve. The influence of EOOG on E. coli strains caused a reduction in cell density, which was determined by OD values. The establishment of the stationary phase was at least $50 \%$ below the control curve, except for the ATCC strain, which had a 20\% reduction only. The growth level was determined by the area under the curve (AUC), and the treated groups showed a significant reduction $(p<0.01)$ for all tested strains, as shown by bar graphs in Figure 2.

\subsection{Combination between EOOG and Antibiotics}

The 5B and P12 strains, which presented resistance profiles by the VITEK ${ }^{\circledR} 2$ system (BioMérieux, Marcy-l'Étoile, France), were used to evaluate the EOOG and antibiotics interaction performed by checkerboard assay. S. aureus (5B) and E. coli (P12) obtained the same MIC for ciprofloxacin (CIP), $62.50 \mu \mathrm{g} / \mathrm{mL}$. The OXA bacteriostatic concentration was determined only against 5B, which was 2000 $\mu \mathrm{g} / \mathrm{mL}$, since this kind of antibiotic is not clinically recommended to treat E. coli-related illnesses.

The combination of the EOOG with antibiotics, CIP and OXA had fractional inhibitory concentration index (FIC $i$ ) of 0.516 and 0.562 , respectively, showing additive effect interaction between them (Table 3). In both cases the combination with antibiotics allowed to decrease by half the EO concentration, only. Furthermore, the CIP and OXA doses were 16- and 64-fold less, respectively, than individual use. In relation to the P12 strain, the effect of the EOOG/CIP combination was antagonistic 
$(\mathrm{FIC} i=2)$. The individual and combined MIC of the EO and antibiotic, as well as the FIC $i$ interpretation and reduction in drug concentration, are shown in Table 3.

Table 3. Fractional inhibitory concentrations index (FICi) of OXA and CIP combined with EOOG for $S$. aureus (5B) and E. coli (P12) microorganisms.

\begin{tabular}{|c|c|c|c|c|c|c|}
\hline \multirow{2}{*}{ Microorganisms } & \multirow{2}{*}{ Combination } & \multicolumn{2}{|c|}{ MIC ( $\mu \mathrm{g} / \mathrm{mL})$} & \multirow{2}{*}{ FIC $i$} & \multirow{2}{*}{ Interpretation } & \multirow{2}{*}{$\begin{array}{c}\text { Drug } \\
\text { Reduction }\end{array}$} \\
\hline & & Individual & Combined & & & \\
\hline \multirow{4}{*}{ S. aureus (5B) } & EOOG & 2000 & 1000 & \multirow{2}{*}{0.516} & \multirow{2}{*}{ Additive } & $2 x$ \\
\hline & OXA & 2000 & 31.25 & & & $64 x$ \\
\hline & EOOG & 2000 & 1000 & \multirow{2}{*}{0.562} & \multirow{2}{*}{ Additive } & $2 x$ \\
\hline & CIP & 62.50 & 3.90 & & & $16 x$ \\
\hline \multirow{2}{*}{ E. coli (P12) } & EOOG & 1000 & 1000 & \multirow{2}{*}{2.000} & \multirow{2}{*}{ Antagonistic } & NR \\
\hline & CIP & 62.50 & 62.50 & & & NR \\
\hline
\end{tabular}

Notes: NR: no reduction. OXA: oxacillin. CIP: ciprofloxacin.

\subsection{Activity on Preformed Biofilm}

The EOOG activity against the biofilm of S. aureus (5B) and E. coli (P12), pre-established for 24 and $12 \mathrm{~h}$, respectively, was evaluated according to biomass by the crystal violet method and cell enumeration by CFU count (Figure 3).

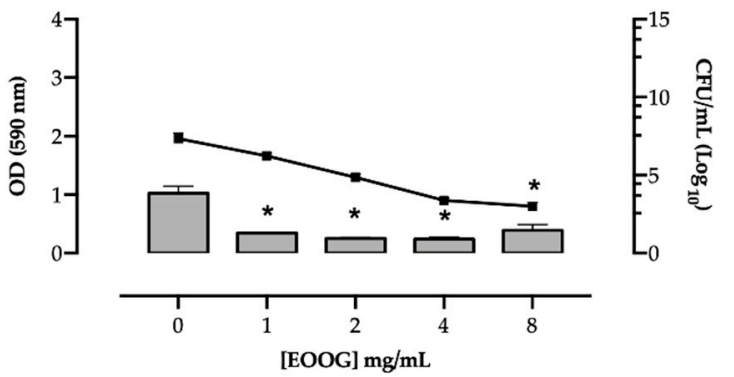

(a)

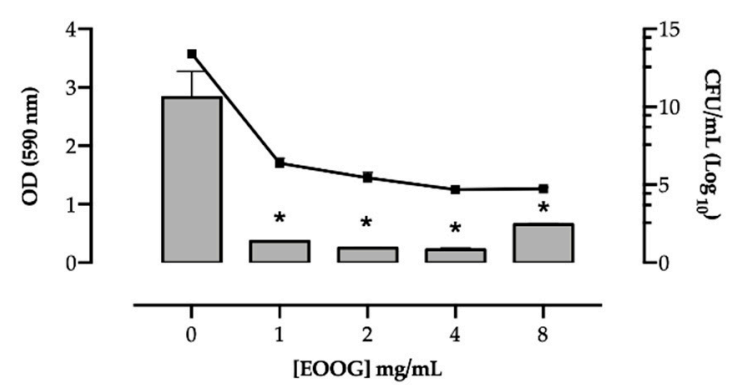

(b)

Figure 3. Antibiofilm activity of different concentrations of EO of Ocimum gratissimum L. against preformed biofilms of S. aureus 5B (a) and E. coli P12 (b), respectively. Biomass quantification by crystal violet staining (OD $590 \mathrm{~nm}$, bars) and cell enumeration by colony count $\left(\log _{10} \mathrm{CFU} / \mathrm{mL}\right.$, $\left.\operatorname{lines}\right)$. * Statistically different by ANOVA $(p<0.01)$ compared to untreated cells.

The strains tested have an equally high capacity for biofilm formation. However, E. coli produced 2.75-fold more biomass and an additional six log units of viable cells into the biofilm than $S$. aureus, even when less time $(12 \mathrm{~h})$ is given for biofilm development. After EOOG treatment $(4 \mathrm{~h})$, these features decreased significantly for both 5B and P12 strains. At a lower concentration, $1 \mathrm{mg} / \mathrm{mL}$, the EOOG-treated biofilm presented a great reduction, mainly for the E. coli strain, which decreased the biomass by 12-fold, and declined in the number of viable cells in the biofilm by eight $\log _{10}$ units. According to $S$. aureus, these values were discretely lower, the biomass reduced 4 -fold, and the CFU count decreased by four $\log _{10}$ units. In both strains, the EOOG was unable to eradicate the biofilm, even at a higher concentration, where some remaining viable cells were detectable.

\subsection{Scanning Electron Microscopy}

The preformed biofilm structure of S. aureus 5B (24 h) and E. coli P12 (12 h), treated and untreated with EOOG, were evaluated through scanning electron microscopy (SEM). Comparative analysis of SEM showed a significant reduction in cell density in the biofilm after $4 \mathrm{~h}$ of EOOG treatment when compared to control conditions in both strains (Figure 4). 

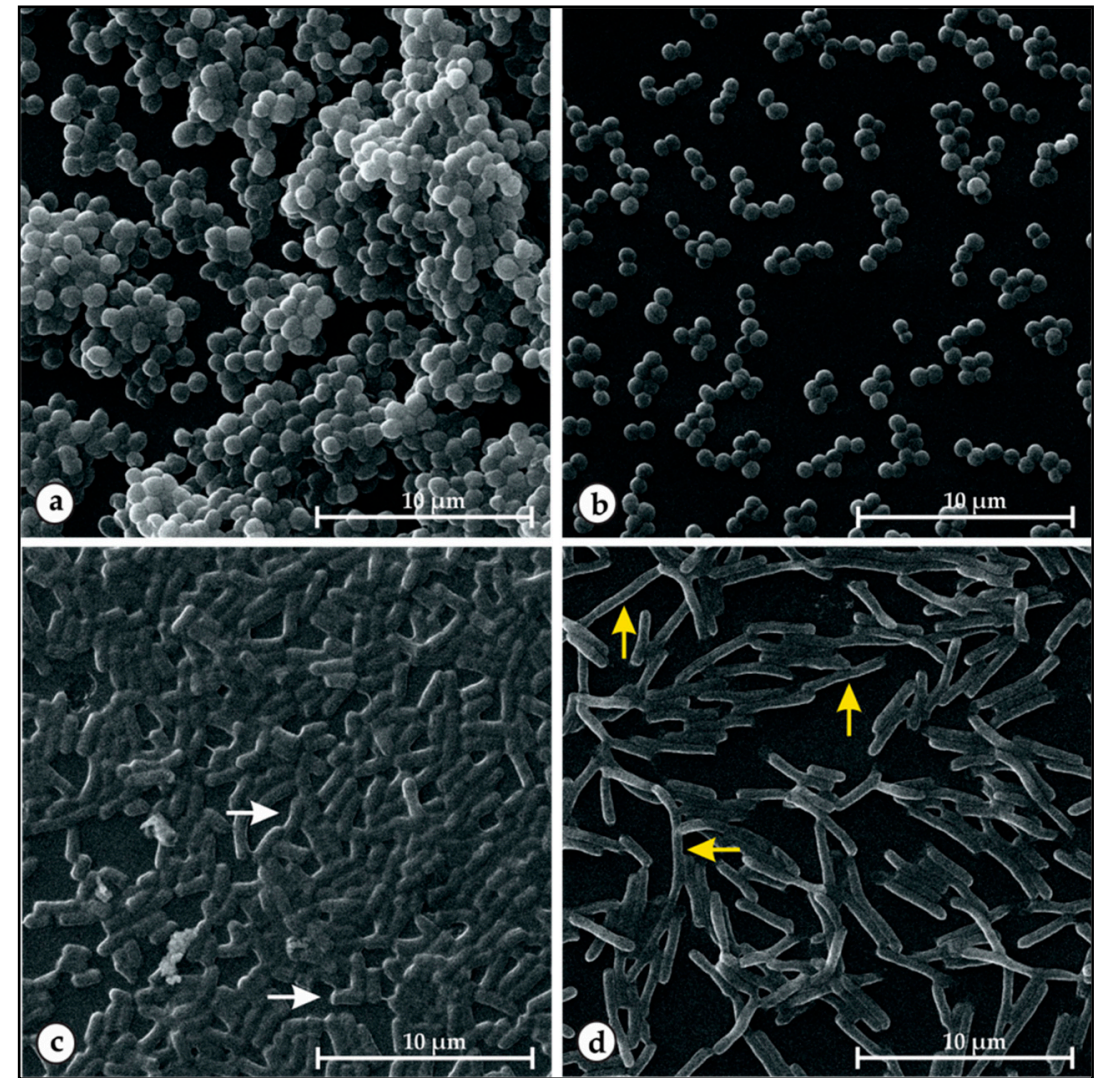

Figure 4. Scanning electron microscopy images of preformed biofilms of S. aureus (5B) and E. coli (P12) treated with the EO of Ocimum gratissimum L. (EOOG) at MIC doses. Untreated 5B (a) and P12, (c) and EOOG-treated 5B, (b) and P12 (d) cells. In the control condition, E. coli presented rod-shaped (white arrow) cells, and after EOOG treatment, the P12 cells displayed an elongated (yellow arrow) morphology status.

In control groups, it is possible to verify cell clusters forming a well-defined three-dimensional structure, mainly for 5B. EOOG treatment at MIC doses was able to disrupt the bacterial community of both strains, reducing the number of adsorbed cells in the biofilm. EOOG-treated P12 cells were clearly found elongated compared to the cells in the control condition, as shown in Figure 4c,d, respectively.

\section{Discussion}

In the present study, it was found that dried leaves of O. gratissimum L. collected from Alto da Pipira, located in Maranhão State, Brazil, obtained yield of $1.66 \% w / w$. Similar amount $(1.12 \% w / w)$ was extracted from dry aerial parts of O. gratissimum cultivated in Londrina, State of Paraná, Brazil [33]. Yield of $0.21 \% w / w$ was also found using fresh leaves and branches obtained from Uganda, East African country [34]. Thus, the type of raw material used for extraction process, dry or fresh samples, may have impact on the essential oil yield. It was possible to identify $99.42 \%$ of the constituents, corresponding to 19 compounds, among which, eugenol $(74.83 \%)$ and 1,8-cineole $(15.16 \%)$ were the most abundant in the EOOG composition (Table 1). Other studies have also reported eugenol as the main constituent of this oil; however, the second most present component has been different, such as methyl eugenol, germacrene-D [35], terpinolene [36], citronellal [37], and $\alpha$-ocimene [38].

It has been proven that vegetative stages can influence the constitution of EOs [39]. EOOG obtained in the Republic of Benin, West Africa, showed a difference in the quantification of prevalent constituents in relation to vegetative, pre-flowering, and flowering stages. In addition, diverging from the findings in the present research, other major constituents, $p$-cymene and thymol, were detected [40]. However, as seen above, a range of variables, such as seasonality, circadian rhythm, temperature, 
water availability, incidence of ultraviolet radiation, nutrient availability, altitude, and pathogen attack to plants, can interfere with a plant's secondary metabolism and can considerably modify the OE composition [41].

Currently, due to the emergence and spread of MDR bacteria, it is necessary to search for new alternatives to combat this kind of pathogen, and to reverse the deficiency of antibiotic options against these infections [42]. The present investigation corroborated the promising applications of EOs as an alternative therapy against bacterial isolates, such as S. aureus and E. coli. Initially, the EOOG antimicrobial activity was accessed by disk diffusion and microdilution techniques to verify the sensibility profile of the tested strains. Thus, EOOG was effective mainly at concentrations between 1000 and $2000 \mu \mathrm{g} / \mathrm{mL}$. However, different EOs or chemotypes from the same EO may have a wide MIC variety (from 50 to $6400 \mu \mathrm{g} / \mathrm{mL}$ ) against foodborne pathogens [43].

Although the literature has shown Gram-negative bacteria to be more resistant to EOs compared to Gram-positive [44,45], it was possible to verify that EOOG had a greater effect against $E$. coli than S. aureus strains, as also demonstrated by the SEM images (Figure 4). This differential EO action on microbial species was also observed in the bacterial growth curve under sub-MIC EOOG exposure. The treated cells clearly had a lag phase extended compared to the control. However, the exponential growth was recovered, and S. aureus easily reached optical density measurements similar to the control, while E. coli had its growth level reduced by half, as shown by the AUC graphs in Figure 2.

The microbial behavior in response to EO exposure could be due to several reasons, one of which is the ability of small molecules, such as eugenol and 1,8-cineole (Figure 1), major compounds of EOOG, to interact with the outer surface of the cells $[44,46,47]$. In addition, some bacteria have an adaptive capacity to protect itself against the stress caused by OE attacks that alter the fatty acid profile of the cytoplasmic membrane $[48,49]$. Therefore, the main bactericidal action of the EO is attributed to the ability to interact with the cell membrane, altering its permeability, causing extravasation of intracellular constituents, and resulting in bacterial death [50]. Furthermore, EOs are made up of various compounds, and it is still believed that this makes it difficult to develop bacterial resistance when compared to antibiotics that have only one cell target, suggesting that EOs can be used to fight MDR bacteria [51].

Natural products also fit as components of interest for combinatorial therapies against MDR bacterial infections [52,53]. Previous studies have reported interactions between EO constituents and conventional antibiotics against E. coli MDR [54-56]. Oliva et al. (2018), using terpinen-4-ol-rich EO of Melaleuca alternifolia, found synergistic activity with OXA against methicillin-resistant $S$. aureus (MRSA) [57]. This effect might be attributed to the ability of the EO compound, such as eugenol/thymol, to increase the antibiotic permeation into the bacterial cell $[55,58]$. Although many researchers seek to demonstrate a synergism between $\mathrm{EO}$ and antibiotics [59-62], it should be considered that combinations that result in additive effects may be as effective as synergistic effects because, with minor amounts of antibiotics, they provide satisfactory effects [63], as shown by the 16- and 64-fold decreases in CIP and OXA concentrations, respectively, against the 5B strain. Concerning the P12 strain, EOOG combined with CIP was unable to alter the strain resistance, showing an antagonistic effect. However, EOOG in combination with other antibiotics should not be ruled out, since the majority EOOG compound (eugenol) has been explored in previous studies and has demonstrated a synergistic effect using penicillin and colistin $[49,54]$.

Another applicability of EOs is related to biofilm disruption [64]. Since biofilm formation is a virulence factor for many microorganisms, such as $S$. aureus and E. coli, and increases tolerance to antimicrobial drugs, new strategies to combat them are sought $[65,66]$. Budzyńska et al. (2017) described the antibiofilm activity of EOs from cloves, which have a high eugenol percentage (86.2\%), and were able to reduce $S$. aureus mono- and dual-species with a Candida albicans biofilm [67]. In other case, the EO from bay leaves, cloves, and berry peppers with more than $60 \%$ eugenol in their constitution show important activities against antibiotic-resistant biofilms of E. coli O157:H7 [68]. 
Combined with these results, this study shows that eugenol-rich EOOG is able to reduce biomass and the number of viable cells in biofilms from S. aureus and E. coli MDR.

The mechanism of action against these established cell clusters may be through the disruption of 3D structures and/or the direct killing of the bacteria in the biofilm [69-71]. Through SEM images (Figure 4), it can be noted that the cellular damage to $S$. aureus was less significant than that to $E$. coli, since the Gram-negative cell showed a considerable difference in cellular dimensions between EOOG-treated and -untreated bacteria. As shown before, this morphological status could be related to interference in the cell division process due to stress responses, including DNA damage and the inhibition of replication [72,73]. Previous research has also associated antibiofilm activity with the ability of these natural compounds to disturb the bacterial communication mechanism, quorum sensing, and the expression of virulence factors that are responsible for the survival characteristics of the biofilm [74-76].

\section{Materials and Methods}

\subsection{Plant Material}

Fresh leaves of O. gratissimum L. were collected in the morning at Alto da Pipira ( $5^{\circ} 26^{\prime} 4.07^{\prime \prime} \mathrm{S}$, $47^{\circ} 17^{\prime} 45.83^{\prime \prime} \mathrm{W}$ ), in the State of Maranhão, in the northeast region of Brazil. The botanical identification was performed by Prof. Dr. Eduardo Bezerra de Almeida Júnior, and the voucher specimen (No. 11175) was deposited and cataloged in the collection of the Maranhão Herbarium (MAR) of the Department of Biology (CCBS) of the Federal University of Maranhão (UFMA), Maranhão, Brazil.

\subsection{Essential Oil Extraction}

The fresh leaves of $O$. gratissimum were dried in room temperature for four days. Then, the dried material $(76.84 \mathrm{~g})$ was mixed with $2.5 \mathrm{~L}$ of distilled water and subjected to hydrodistillation in a Clevenger-type apparatus for $3 \mathrm{~h}$ to afford a pale yellow oil. The isolated oil, after drying over anhydrous sodium sulfate $\left(\mathrm{Na}_{2} \mathrm{SO}_{4}\right)$ and filtration, was stored in sealed glass vials and maintained under refrigeration until further analysis. Total oil yield was expressed as a percentage ( $\mathrm{g}$ per $100 \mathrm{~g}$ of dried leaves).

\subsection{Chemical Composition of EOOG}

Qualitative analysis of the chemical composition of the essential oil was performed with a gas chromatograph (GC) coupled with a mass spectrometer (MS), Agilent Model GC-7890B/MSD-5977A (quadrupole), with an electron impact at $70 \mathrm{eV}$, an HP-5MS methylpolysiloxane column (30 $\mathrm{m} \times$ $0.25 \mathrm{~mm} \times 0.25 \mu \mathrm{m}$, Agilent), a $1 \mathrm{~mL} / \mathrm{min}$ flowing helium carrier gas, an injector temperature of 250 ${ }^{\circ} \mathrm{C}$, a detector temperature of $150{ }^{\circ} \mathrm{C}$, and a transfer line at $280^{\circ} \mathrm{C}$. The chromatographic oven was programmed as follows: an initial temperature of $70^{\circ} \mathrm{C}$, with a heating ramp of $4{ }^{\circ} \mathrm{C} / \mathrm{min}$ to $180^{\circ} \mathrm{C}$, and an increase of $10^{\circ} \mathrm{C} / \mathrm{min}$ to $250^{\circ} \mathrm{C}$ at the end of the run $(34.5 \mathrm{~min})$.

Quantitative analysis of the chemical composition of the oil was carried out by GC coupled to a flame ionization detector (FID), Shimadzu Model CG-2010 Plus instrument, with an RTX-5 methylpolysiloxane column $(30 \mathrm{~m} \times 0.25 \mathrm{~mm} \times 0.25 \mu \mathrm{m})$, a 1:30 flow split injection mode, a 1.00 $\mathrm{mL} / \mathrm{min}$ flow nitrogen carrier gas, an injector temperature of $250^{\circ} \mathrm{C}$, and a detector temperature of 280 ${ }^{\circ} \mathrm{C}$. The programming of the chromatographic oven was similar to that used in the GC/MS analysis.

The constituents' percentages were calculated by the integral area of their respective peaks, related to the total area of all the constituents of the sample. The various constituents of the EO were identified by visually comparing their mass spectra with those in the literature [32] and the spectra provided by the equipment database (NIST11), and by comparing retention rates with those in the literature [32]. A standard solution of $\mathrm{n}$-alkanes $\left(\mathrm{C}_{9}-\mathrm{C}_{30}\right)$ was injected using the same chromatographic conditions of the sample to calculate the retention index for each peak, as described by Dool and Kratz (1963) [77]. 


\subsection{Preparation of Antimicrobial Solutions}

EOOG stock solution was prepared in Brain Heart Infusion broth (BHI, Acumedia ${ }^{\circledR}$, Michigan, USA) with $1 \%$ tween 80 sterile (VETEC Fine Chemistry LTDA, Rio de Janeiro, Brazil) at 16 mg/mL. From the oil density $(1.0074 \mathrm{~g} / \mathrm{mL})$, it was firstly mixed EOOG $(16 \mu \mathrm{L})$ with tween $80(10 \mu \mathrm{L})$ and bring volume to $1 \mathrm{~mL}$ with fresh BHI $(974 \mu \mathrm{L})$. It was considered as control group (untreated cells) in the experimental assays, only broth media plus tween 80 in an equivalent amount for each EOOG concentration tested. Oxacillin sodium (OXA, Blau Pharmaceutical SA, Sao Paulo, Brazil) and ciprofloxacin (CIP, Fresenius Laboratory Kabi, Sao Paulo, Brazil) antibiotics, obtained commercially, were prepared according to manufacture note, and the concentration was adjusted to $32 \mathrm{mg} / \mathrm{mL}$.

\subsection{Bacterial Strains and Culture Conditions}

EOOG activity was evaluated against two representatives, Gram-negative and -positive bacterial cells, four strains of $S$. aureus and E. coli species. The standard strains from the American Type Culture Collection (ATCC, USA) were used as sensitive antibiotic strains. The clinical S. aureus were isolated and identified in the Laboratory of Microbiology of the Santa Casa de Misericórdia de Sobral, CE, Brazil, as part of the hospital routine. E. coli strains were isolated from fresh tilapia fillets (Oreochromis niloticus) obtained from the retail trade of Sobral, CE, Brazil [78]. The confirmatory identification and resistance profile of bacterial strains were determined by the VITEK ${ }^{\circledR} 2$ system (BioMérieux, MarcyL'Etoile, France). The source and resistance profile of the microorganisms selected are described below (Table 4).

Table 4. Antibiotic resistance profile obtained by the VITEK ${ }^{\circledR} 2$ system.

\begin{tabular}{cll}
\hline Staphylococcus aureus & Source & \multicolumn{1}{c}{ Antibiotic Resistance } \\
\hline Standard & ATCC 6538 & Sensitive \\
2B & Soft tissues & ERT, CLIN e BZP \\
5B & Human blood & ERT, CLIN, CIP, NOR, MOX, BZP, OXA e RIP (I) \\
7B & Human blood & BZP e OXA \\
\hline Escherichia coli & & \\
Standard & ATCC 11303 & Sensitive \\
P12 & Fish fillet & AMP, CFL, CIP, NOR, NAL e AMC (I) \\
P25 & Fish fillet & AMP, CFL (I) e AMC (I) \\
P36 & Fish fillet & AMP, CFL (I) e AMC (I) \\
\hline
\end{tabular}

Notes: AMC: Amoxicillin/clavulanic acid. AMP: Ampicillin. BZP: Benzylpenicillin. CFL: Cefelotin. CIP: Ciprofloxacin. CLIN: Clindamycin. ERT: Erythromycin. MOX: Moxifloxacin. NAL: Nalidixic acid. NOR: Norfloxacin. OXA: Oxacillin. (I): Intermediate resistance.

Separately, cells were cultured from stock culture and maintained at $-80^{\circ} \mathrm{C}$ in $5 \mathrm{~mL}$ of BHI broth at $37^{\circ} \mathrm{C}$ overnight before each experimental procedure. Afterward, $50 \mu \mathrm{L}$ were inoculated into the same culture media (1:10) and grown at $37^{\circ} \mathrm{C}$ until late in the exponential phase. Prior to biological assays, the turbidity of bacterial suspension was adjusted against the standard $0.5 \mathrm{McF}$ arland $\left(10^{8} \mathrm{CFU} / \mathrm{mL}\right)$ and diluted with fresh $\mathrm{BHI}$ to reach an appropriate cell concentration for each method.

\subsection{Antimicrobial Activity of EOOG}

The antibacterial activity of the EO was firstly determined by the paper disk diffusion method. Briefly, a sterile swab was dipped into each tested bacterial suspension adjusted to $10^{8} \mathrm{CFU} / \mathrm{mL}$ in saline, rotated against the tube wall, and rubbed in several directions on the whole surface of Mueller-Hinton agar (MHA) plates (Acumedia ${ }^{\circledR}$, Michigan, USA). Afterward, three disks $6 \mathrm{~mm}$ in diameter (Biomérieux, Marcy-l'Etoile, France) and impregnated with $5 \mu \mathrm{L}$ of pure EOOG were placed equidistantly on the MHA surface. After $24 \mathrm{~h}$ of incubation at $37^{\circ} \mathrm{C}$, the antibacterial effect was evaluated by measuring the diameter of inhibitory zones (DIZ) in millimeters, and the results were expressed as means from three determinations. 
The minimum inhibitory concentrations (MICs) were determined using a microdilution method following the standard CLSI (Clinical and Laboratory Standards Institute, M07-A10) protocol [79]. Serial two-fold dilutions of $100 \mu \mathrm{L}$ were prepared with BHI broth in 96-well microtiter plates (KASVI, Paraná, Brazil), obtaining EOOG concentrations from 250 to $8000 \mu \mathrm{g} / \mathrm{mL}$. For antibiotic CIP and OXA, concentrations ranging from 0.25 to $8000 \mu \mathrm{g} / \mathrm{mL}$ and from 0.25 to $256 \mu \mathrm{g} / \mathrm{mL}$, respectively, were used. Afterward, $100 \mu \mathrm{L}$ of the bacterial suspension $\left(10^{6} \mathrm{CFU} / \mathrm{mL}\right)$ were added to each well, yielding a final cell concentration of $5 \times 10^{5}$, and plates were incubated for $24 \mathrm{~h}$ at $37^{\circ} \mathrm{C}$. The lowest concentration capable of inhibiting the visible bacterial growth was defined as the MIC. To determine minimum bactericidal concentrations (MBCs), $10 \mu \mathrm{L}$ were collected from each well that contained no bacterial growth and were plated on the $\mathrm{BHI}$ agar. The $\mathrm{MBC}$ was recorded as the lowest concentration capable of inhibiting bacterial growth on the agar surface after $24 \mathrm{~h}$ of incubation at $37^{\circ} \mathrm{C}$. All experiments were performed in triplicate, with three independent repeats.

\subsection{Kinetic Growth Assay}

The growth curve assay was performed for all bacterial strains in 96-well polystyrene microtiter plates, as described by Field et al. (2010), with modifications [80]. The bacterial suspension adjusted $\left(10^{6} \mathrm{CFU} / \mathrm{mL}\right)$ and EOOG at sub-inhibitory concentration (1/2MIC) $(1: 1, v / v)$ was added to each well, and the kinetic growth was determined over a time course. Optical density $\left(\mathrm{OD}_{620}\right)$ was measured every hour to evaluate bacterial density for a period of 24 and $18 \mathrm{~h}$ for S. aureus and E. coli strains, respectively. The growth level was quantified by the area under the curve (AUC), which was calculated as a metric absorbance $(620 \mathrm{~nm})$ distribution as a function of time. For each condition, an average value from six replicas was given. It is important to highlight that experimental protocols were carried out with selected strains from each bacterial species with a multiresistance profile (5B and P12).

\subsection{Checkerboard Assay}

The combination activity of antimicrobial compounds was determined by checkerboard assay in 96-well microtiter plates [81]. The combinations used were as follows: EOOG + OXA/CIP for S. aureus (5B) and EOOG + CIP for E. coli (P12). First, serial two-fold dilutions of drugs were prepared with BHI broth separately. Using a 96-well microtiter plate, $50 \mu \mathrm{L}$ of each substance $(1: 1 v / v)$ were added in rows (EOOG), in ascending concentrations, and the antibiotics (CIP or OXA) were similarly distributed among the columns. Thus, each well held a unique combination of concentrations of the two substances. Afterward, $100 \mu \mathrm{L}$ of bacterial inoculum $\left(10^{6} \mathrm{CFU} / \mathrm{mL}\right)$ were added to the wells and incubated at $37^{\circ} \mathrm{C}$ for $24 \mathrm{~h}$. The analysis of the interaction results was performed by the fractional inhibitory concentration index (FICi), defined as the sum of the MIC of the combined substances divided by the MIC of the isolated substances and and categorized as: Synergism (FIC $i \leq 0.5$ ), additive (FIC $i>0.5$ to $\leq 1$ ), indifferent (FIC $i>1$ to $<2$ ), or antagonism (FIC $i \geq 2$ ), according to European Committee for Antimicrobial Susceptibility Testing (EUCAST) [82].

\subsection{Antibiofilm Activity}

The EOOG antibiofilm assay was verified on preformed biofilms, 12 and $24 \mathrm{~h}$ for E. coli (P12) and S. aureus (5B), respectively, using 96-well polystyrene microtiter plates, according to Yadav et al. (2015), with modifications [69]. After biofilm formation, the wells were washed three times with PBS (Phosphate-Saline Buffer 0.1 M; pH 7.4) to remove the planktonic and weakly attached cells. Afterward, the biofilm was treated with $200 \mu \mathrm{L}$ of essential oil at decreasing concentrations ( 8000 to $1000 \mu \mathrm{g} / \mathrm{mL}$ ) for $4 \mathrm{~h}$ at $37^{\circ} \mathrm{C}$. The biofilm was quantified according to biomass and the number of viable cells by crystal violet staining (CV) and colony forming units (CFU), respectively. Each technique was performed in triplicate, with three independent experiments.

Firstly, $200 \mu \mathrm{L}$ of methanol PA (Dinâmica, São Paulo, Brazil) were added to treated biofilm wells for $15 \mathrm{~min}$ to fix the adhered cells. Afterward, it was removed, and the microplate was left to dry at room temperature. Thus, $200 \mu \mathrm{L}$ of $0.1 \%$ crystal violet (Synth ${ }^{\circledR}$, Sao Paulo, Brazil) were added 
over a period of $10 \mathrm{~min}$. After washing the wells using distilled water, the biofilm-bound dye was solubilized in $200 \mu \mathrm{L}$ of 33\% glacial acetic acid (Dinâmica, Sao Paulo, Brazil). After that, the absorbance was measured using an optical density reader (SpectraMax ${ }^{\circledR}$ Paradigm ${ }^{\circledR}$ Molecular Devices, San Jose, California, USA) at $590 \mathrm{~nm}$. Secondly, to determine the viable number of cells in the EOOG-treated biofilm, $200 \mu \mathrm{L}$ of PBS were added to each well, and the microplate was subjected to ultrasound (GNATUS, São Paulo, Brazil) for 5 min to detach the biofilm-embedded bacteria. Serial ten-fold dilutions were then prepared from that cell suspension, and $10 \mu \mathrm{L}$ were plated in BHI agar. After $18 \mathrm{~h}$ of incubation at $37^{\circ} \mathrm{C}$, the total of enumerated cells was expressed in $\log _{10} \mathrm{CFU} / \mathrm{mL}$ from the average of the number of CFUs of three different wells from the same replicate.

\subsection{Scanning Electron Microscopy}

Structural arrangement changes of S. aureus (5B) and E. coli (P12) biofilms induced by EOOG (1xMIC) treatment were evaluated by scanning electron microscopy (SEM-Inspect S50-FEI Company ${ }^{\circledR}$, Oregon, USA), according to Yadav et al. (2015), with modifications [69]. The biofilm was formed from a cell suspension $\left(10^{6}\right.$ cells $\left./ \mathrm{mL}\right)$ in fresh BHI for $24 \mathrm{~h}(5 \mathrm{~B})$ and $12 \mathrm{~h}(\mathrm{P} 12)$ at $37^{\circ} \mathrm{C}$ in 24-well plates containing glass slides $(1 \times 1 \mathrm{~cm})$. The slides were then washed three times with $0.1 \mathrm{M}$ PBS, and surface adsorbed cells were treated with EOOG at MIC values against 5B and P12, 2000 and $1000 \mu \mathrm{g} / \mathrm{mL}$, respectively, for $4 \mathrm{~h}$ at $37^{\circ} \mathrm{C}$. For the control group, only fresh BHI with tween 80 was used. Before SEM analysis, the cells were pre-fixed with $2 \%$ glutaraldehyde, dehydrated with an alcohol solution at 10, 30, 50, 70, 90, and 100\% for $20 \mathrm{~min}$ each, and dried at room temperature. The slides were placed on carbon tape on the aluminum sample holder (stubs), coated with gold (Emitech Q150T, Lewes, UK), and viewed via SEM at $20 \mathrm{~kW}$.

\subsection{Statistical Analysis}

Antimicrobial and antibiofilm activity assays performed in triplicate were presented as the mean \pm standard deviations (SD). Data were statistically analyzed using GraphPad Prism 8.0 software (GraphPad Software, Inc., San Diego, CA, USA) applying analysis of variance (ANOVA) with Tukey's post hoc test. Differences between treated and control groups were considered significant when $p<0.01$. The graphs generated in the growth curve test were used to determine the area under the curve (AUC).

\section{Conclusions}

The EO from dried leaves of O. gratissimum L. obtained in Maranhão State, Brazil, demonstrated antibacterial activity against representative Gram-negative and -positive strains, S. aureus and E. coli, with a multidrug resistance profile. In addition, the ability of EO combined with clinical antibiotics to increase the sensitivity of $S$. aureus to OXA and CIP was determined. It was possible to observe the action against established biofilms as well as the reduction in bacterial load within S. aureus and E. coli biofilms. Considering all the results obtained, the EOOG can be used as an alternative for new therapies against MDR bacteria, for instance, like formulations of antibacterial creams or gels containing OEs for topical applications or even to produce EO-based wound dressings.

Author Contributions: Conceptualization: V.A.C. and F.E.A.C.J.; data curation: R.S.M., Á.M.A.A. and V.A.C.; formal analysis: R.S.M.; Á.M.A.A., A.M.G.P. and M.N.C.M.; funding acquisition: H.S.d.S. and F.E.A.C.J.; investigation: R.S.M., Á.M.A.A., A.M.G.P., R.R.R., R.M.B.C., M.N.C.M., P.H.R.L., G.A.G., T.H.S.R., I.L.P., R.A.C. and G.S.B.; methodology: R.S.M., Á.M.A.A. and G.A.G.; project administration: F.E.A.C.J.; resources: G.A.G.; supervision: V.A.C.; Writing—Original draft: R.S.M., Á.M.A.A. and G.A.G.; Writing—Review \& edition: R.A.C. and V.A.C.

Funding: This research was funded by the Foundation for Support for Research and Scientific and Technological Development of Maranhão, (FAPEMA-Brazil), grant number 00986/17 - Universal Program.

Acknowledgments: The LaBAM team is grateful to the Coordination for the Improvement of Higher Education Personnel (CAPES) for the financial support, and to the University Center INTA (UNINTA) for encouragement to 
carry out the research. We are also thankful to Center for Analytical Microscopy from Federal University of Ceará (UFC) for assistance with SEM images, which improved the manuscript significantly.

Conflicts of Interest: The authors declare no conflict of interest.

\section{References}

1. Vivas, R.; Barbosa, A.A.T.; Dolabela, S.S.; Jain, S. Multidrug-resistant bacteria and alternative methods to control them: An overview. Microb. Drug. Resist. 2019, 25, 890-908. [CrossRef] [PubMed]

2. Karam, G.; Chastre, J.; Wilcox, M.H.; Vincent, J.L. Antibiotic strategies in the era of multidrug resistance. Crit. Care 2016, 20, 136. [CrossRef] [PubMed]

3. Ma, D.S.L.; Tan, L.T.H.; Chan, K.G.; Yap, W.H.; Pusparajah, P.; Chuah, L.H.; Ming, L.C.; Khan, T.M.; Lee, L.H.; Goh, B.H. Resveratrol-potential antibacterial agent against foodborne pathogens. Front. Pharmacol. 2018, 9, 102. [CrossRef] [PubMed]

4. Davies, S.K.; Fearn, S.; Allsopp, L.P.; Harrison, F.; Ware, E.; Diggle, S.P.; Filloux, A.; McPhail, D.S.; Bundy, J.G. Visualizing antimicrobials in bacterial biofilms: Three-dimensional biochemical imaging using TOF-SIMS. mSphere 2017, 2, e00211-e00217. [CrossRef]

5. Makovcova, J.; Babak, V.; Kulich, P.; Masek, J.; Slany, M.; Cincarova, L. Dynamics of mono- and dual-species biofilm formation and interactions between Staphylococcus aureus and Gram-negative bactéria. Microb. Biotechnol. 2017, 10, 819-832. [CrossRef]

6. Thurlow, L.R.; Hanke, M.L.; Fritz, T.; Angle, A.; Aldrich, A.; Williams, S.H.; Engebretsen, I.L.; Bayles, K.W.; Horswill, A.R.; Kielian, T. Staphylococcus aureus biofilms prevent macrophage phagocytosis and attenuate inflammation in vivo. J. Immunol. 2011, 186, 6585-6596. [CrossRef]

7. Lebeaux, D.; Ghigo, J.M.; Beloin, C. Biofilm-related infections: Bridging the Gap between clinical management and fundamental aspects of recalcitrance toward antibiotics. Microbiol. Mol. Biol. Rew. 2014, 78, 510-543. [CrossRef]

8. van Duin, D.; Paterson, D. Multidrug resistant bacteria in the community: Trends and lessons learned. Infect. Dis. Clin. N. Am. 2016, 30, 377-390. [CrossRef]

9. Elshafie, H.S.; Camele, I. An overview of the biological effects of some Mediterranean essential oils on human health. Biomed Res. Int. 2017, 2017, 9268468. [CrossRef]

10. Sharifi-Rad, J.; Sureda, A.; Tenore, G.C.; Daglia, M.; Sharifi-Rad, M.; Valussi, M.; Tundis, R.; Sharifi-Rad, M.; Loizzo, M.R.; Ademiluyi, A.O.; et al. Biological activities of essential oils: From plant chemoecology to traditional healing systems. Molecules 2016, 22, 70. [CrossRef]

11. Ju, J.; Xie, Y.; Guo, Y.; Cheng, Y.; Qian, H.; Yao, W. Application of edible coating with essential oil in food preservation. Crit. Rev. Food Sci. Nutr. 2018, 59, 2467-2480. [CrossRef] [PubMed]

12. Blowman, K.; Magalhães, M.; Lemos, M.F.L.; Cabral, C.; Pires, I.M. Anticancer properties of essential oils and other natural products. Evid. Based Complement. Alternat. Med. 2018, 2018, 3149362. [CrossRef] [PubMed]

13. Swamy, M.K.; Akhtar, M.S.; Sinniah, U.R. Antimicrobial properties of plant essential oils against human pathogens and their mode of action: An updated review. Evid. Based Complement. Alternat. Med. 2016, 2016, 3012462. [CrossRef] [PubMed]

14. Solórzano-Santos, F.; Miranda-Novales, M.G. Essential oils from aromatic herbs as antimicrobial agents. Curr. Opin. Biotechnol. 2012, 23, 136-141. [CrossRef]

15. Man, A.; Santacroce, L.; Jacob, R.; Mare, A.; Man, L. Antimicrobial activity of six essential oils against a group of human pathogens: A comparative study. Pathogens 2019, 8, 15. [CrossRef]

16. Ebani, V.V.; Nardoni, S.; Bertelloni, F.; Pistelli, L.; Mancianti, F. Antimicrobial activity of five essential oils against bacteria and fungi responsible for urinary tract infections. Molecules 2018, 23, 1668. [CrossRef]

17. Tariqa, S.; Wania, S.; Rasoola, W.; Shafia, K.; Bhata, M.A.; Prabhakarb, A.; Shallaa, A.H.; Rathera, M.A. A comprehensive review of the antibacterial, antifungal and antiviral potential of essential oils and their chemical constituents against drugresistant microbial pathogens. Microb. Pathog. 2019, 103580, 134. [CrossRef]

18. Li, Z.H.; Cai, M.; Liu, Y.S.; Sun, P.L.; Luo, S.L. Antibacterial activity and mechanisms of essential oil from Citrus medica L. Var. Sarcodactylis. Molecules 2019, 24, 1577. [CrossRef] 
19. Zomorodian, K.; Moein, M.; Pakshir, K.; Karami, F.; Sabahi, Z. Chemical composition and antimicrobial activities of the essential oil from Salvia mirzayanii leaves. Evid. Based Complement. Alternat. Med. 2017, 22, 770-776. [CrossRef]

20. Porfírio, E.M.; Melo, H.M.; Pereira, A.M.G.; Cavalcante, T.T.A.; Gomes, G.A.; de Carvalho, M.G.; Costa, R.A.; Catunda Júnior, F.E.A. In vitro antibacterial and antibiofilm activity of Lippia alba essential oil, citral, and carvone against Staphylococcus aureus. Sci. World. J. 2017, 2017, 4962707. [CrossRef]

21. Vasconcelos, S.E.C.B.; Melo, H.M.; Cavalcante, T.T.A.; Catunda Júnior, F.E.A.; de Carvalho, M.G.; Menezes, F.G.R.; de Sousa, O.V.; Costa, R.A. Plectranthus amboinicus essential oil and carvacrol bioactive against planktonic and biofilm of oxacillin- and vancomycinresistant Staphylococcus aureus. BMC Complement. Altern. Med. 2017, 17, 462. [CrossRef] [PubMed]

22. Firmino, D.F.; Cavalcante, T.T.A.; Gomes, G.A.; Firmino, N.C.S.; Rosa, L.D.; de Carvalho, M.G.; Catunda Júnior, F.E.A. Antibacterial and antibiofilm activities of Cinnamomum Sp. essential oil and cinnamaldehyde: Antimicrobial activities. Sci. World J. 2018, 2018, 7405736. [CrossRef] [PubMed]

23. Lagha, R.; Abdallah, F.B.; AL-Sarhan, B.O.; Al-Sodany, Y. Antibacterial and biofilm inhibitory activity of medicinal plant essential oils against Escherichia coli isolated from UTI patients. Molecules 2019, 24, 1161. [CrossRef] [PubMed]

24. Mohr, F.B.M.; Lermen, C.; Gazim, Z.C.; Gonçalves, J.E.; Alberton, O. Antifungal activity, yield, and composition of Ocimum gratissimum essential oil. Genet. Mol. Res. 2017, 16, 1-10. [CrossRef]

25. Brasil. Ministério da Saúde. Plantas Medicinais de Interesse ao SUS-Renisus. 2009. Available online: http://www.saude.gov.br/acoes-e-programas/programa-nacional-de-plantas-medicinais-e-fitoterapicosppnpmf/politica-e-programa-nacional-de-plantas-medicinais-e-fitoterapicos/plantas-medicinais-deinteresse-ao-sus-renisus (accessed on 14 August 2019).

26. Penido, A.B.; de Morais, S.M.; Ribeiro, A.B.; Silva, A.Z. Ethnobotanical study of medicinal plants in Imperatriz, State of Maranhão, Northeastern Brazil. Acta Amazon. 2016, 46, 345-354. [CrossRef]

27. Pandey, A.K.; Singh, P.; Tripathi, N.N. Chemistry and bioactivities of essential oils of some Ocimum species: An overview. Asian Pac. J. Trop. Biomed. 2014, 4, 682-694. [CrossRef]

28. Castro, J.A.M.; Monteiro, O.S.; Coutinho, D.F.; Rodrigues, A.A.C.; da Silva, J.K.R.; Maia, J.G.S. Seasonal and circadian study of a thymol $/ \gamma$-terpinene/p-cymene type oil of Ocimum gratissimum $\mathrm{L}$. and Its antioxidant and antifungal effects. J. Braz. Chem. Soc. 2019, 30, 930-938. [CrossRef]

29. Iwalokun, B.A.; Gbenle, G.O.; Adewole, T.A.; Smith, S.I.; Akinsinde, K.A.; Omonigbehin, E.O. Effects of Ocimum gratissimum $\mathrm{L}$ essential oil at subinhibitory concentrations on virulent and multidrug-resistant Shigella strains from Lagos, Nigeria. Apmis 2003, 111, 477-482. [CrossRef]

30. Silva, N.C.C.; Fernandes Júnior, A. Biological properties of medicinal plants: A review of their antimicrobial activity. J. Venom. Anim. Toxins Incl. Trop. Dis. 2010, 16, 402-413. [CrossRef]

31. Intorasoot, A.; Chornchoem, P.; Sookkhee, S.; Intorasoot, S. Bactericidal activity of herbal volatile oil extracts against multidrug-resistant Acinetobacter baumannii. J. Ethnopharmacol. 2017, 6, 218-222. [CrossRef]

32. Adams, R.P. Identification of Essential Oil Components by Gas Chromatography/Mass Spectrometry, 4th ed.; Allured Publishing Corporation: Carol Stream, IL, USA, 2007.

33. Faria, T.J.; Ferreira, R.S.; Yassumoto, L.; de Souza, J.R.P.; Ishikawa, N.K.; Barbosa, A.M. Antifungal activity of essential oil isolated from Ocimum gratissimum L. (eugenol chemotype) against phytopathogenic fungi. Braz. Arch. Biol. Technol. 2006, 49, 867-871. [CrossRef]

34. Ocheng, F.; Bwanga, F.; Joloba, M.; Softrata, A.; Azeem, M.; Pütsep, K.; Borg-Karlson, A.K.; Obua, C.; Gustafsson, A. Essential oils from Ugandan aromatic medicinal plants: Chemical composition and growth inhibitory effects on oral pathogens. Evid. Based Complement. Alternat. Med. 2015, 2015, 230832. [CrossRef] [PubMed]

35. Matasyoha, L.G.; Matasyoh, J.C.; Wachira, F.N.; Kinyua, M.G.; Muigai, A.W.T.; Mukiama, T.K. Antimicrobial activity of essential oils of Ocimum gratissimum L. from different populations of Kenya. Afr. J. Tradit. Complement. Altern. Med. 2008, 5, 187-193. [CrossRef]

36. Joshi, R.K. Chemical composition, in vitro antimicrobial and antioxidant activities of the essential oils of Ocimum gratissimum, O. sanctum and their major constituents. Indian J. Pharm. Sci. 2013, 75, 457-462. [CrossRef] [PubMed]

37. Saha, S.; Dhar, T.N.; Sengupta, C.; Ghosh, P. Biological activities of essential oils and methanol extracts of five Ocimum species against pathogenic bacteria. Czech J. Food Sci. 2013, 31, 194-202. [CrossRef] 
38. Tangpao, T.; Chung, H.H.; Sommano, S.R. Aromatic profiles of essential oils from five commonly used Thai Basils. Foods 2018, 7, 175. [CrossRef]

39. Kim, D.Y.; Won, K.J.; Hwang, D.; Park, S.M.; Kim, B.; Lee, H.M. Chemical composition, antioxidant and anti-melanogenic activities of essential oils from Chrysanthemum boreale MAKINO at different harvesting stages. Chem. Biodivers. 2018, 15, e1700506. [CrossRef]

40. Kpadonou Kpoviessi, B.G.H.; Ladekana, E.Y.; Kpoviessia, D.S.S.; Gbaguidib, F.; Yehouenoud, B.; Quetin-Leclercq, J.; Figueredoe, G.; Moudachiroub, M.; Accrombessi, G.C. Chemical variation of essential oil constituents of Ocimum gratissimum L. from Benin, and impact on antimicrobial properties and toxicity against Artemia salina LEACH. Chem. Biodivers. 2012, 9, 139-150. [CrossRef]

41. Gobbo-Neto, L.; Lopes, N.P.L. Plantas medicinais: Fatores de influência no conteúdo de metabólitos secundários. Quim. Nova 2007, 30, 374-381. [CrossRef]

42. Yamani, H.A.; Pang, E.C.; Mantri, N.; Deighton, M.A. Antimicrobial activity of Tulsi (Ocimum tenuiflorum) essential oil and their major constituents against three species of bacteria. Front. Microbiol. 2016, 7, 681. [CrossRef]

43. Thielmann, J.; Muranyi, P.; Kazman, P. Screening essential oils for their antimicrobial activities against the foodborne pathogenic bacteria Escherichia coli and Staphylococcus aureus. Heliyon 2019, 5, e01860. [CrossRef] [PubMed]

44. Trombetta, D.; Castelli, F.; Sarpietro, M.G.; Venuti, V.; Cristani, M.; Daniele, C.; Saija, A.; Mazzanti, G.; Bisignano, G. Mechanisms of antibacterial action of three monoterpenes. Antimicrob. Ag. Chemother. 2005, 49, 2474-2478. [CrossRef] [PubMed]

45. Guo, J.J.; Gao, J.P.; Xia, J.L.; Ritenour, M.A.; Li, G.Y.; Shan, Y. Comparative analysis of chemical composition, antimicrobial and antioxidant activity of citrus essential oils from the main cultivated varieties in China. LWT 2018, 97, 825-839. [CrossRef]

46. Cristani, M.; D’Arrigo, M.; Mandalari, G.; Castelli, F.; Sarpietro, M.G.; Micieli, D.; Venuti, V.; Bisignano, G.; Saija, A.; Trombetta, D. Interaction of four monoterpenes contained in essential oils with model membranes: Implications for their antibacterial activity. J. Agric. Food Chem. 2007, 55, 6300-6308. [CrossRef] [PubMed]

47. Lins, L.; Dal Maso, S.; Foncoux, B.; Kamili, A.; Laurin, Y.; Genva, M.; Jijakli, H.M.; De Clerck, C.; Fauconnier, M.L.; Deleu, M. Insights into the relationships between herbicide activities, molecular structure and membrane interaction of cinnamon and citronella essential oils components. Int. J. Mol. Sci. 2019, 20, 4007. [CrossRef]

48. Di Pasqua, R.; Hoskins, N.; Betts, G.; Mauriello, G. Changes in membrane fatty acids composition of microbial cells induced by addiction of thymol, carvacrol, limonene, cinnamaldehyde, and eugenol in the growing media. J. Agric. Food Chem. 2006, 54, 2745-2749. [CrossRef] [PubMed]

49. Wang, Y.M.; Kong, L.C.; Liu, J.; Ma, H.X. Synergistic effect of eugenol with colistin against clinical isolated colistin-resistant Escherichia coli strains. Antimicrob. Resist. Infect. Control. 2018, 7, 17. [CrossRef]

50. Chimnoi, N.; Reuk-ngam, N.; Chuysinuan, P.; Khlaychan, P.; Khunnawutmanotham, N.; Chokchaichamnankit, D.; Thamniyom, W.; Klayraung, S.; Mahidol, C.; Techasakul, S. Characterization of essential oil from Ocimum gratissimum leaves: Antibacterial and mode of action against selected gastroenteritis pathogens. Microb. Pathogenesis. 2018, 118, 290-300. [CrossRef]

51. Yap, P.S.X.; Yiap, B.C.; Ping, H.C.; Lim, S.H.E. Essential oils, a new horizon in combating bacterial antibiotic resistance. Open Microbiol. J. 2014, 8, 6-14. [CrossRef]

52. Palaniappan, K.; Holley, R.A. Use of natural antimicrobials to increase antibiotic susceptibility of drug resistant bacteria. Int. J. Food. Microbiol. 2010, 140, 164-168. [CrossRef]

53. Bhardwaj, M.; Singh, B.R.; Sinha, D.K.; Kumar, V.; Prasanna Vadhana, O.R.; Varan Singh, S.; Nirupama, K.R.; Pruthvishree; Archana Saraf, B.S. Potential of herbal drug and antibiotic combination therapy: A new approach to treat multidrug resistant bacteria. Pharm. Anal. Acta 2016, 7, 1000523. [CrossRef]

54. Gallucci, N.; Casero, C.; Oliva, M.; Zygadlo, J.; Demo, M. Interaction between terpenes and penicillin on bacterial strains resistant to betalactam antibiotics. Mol. Med. Chem. 2006, 10, 30-32.

55. Pei, R.S.; Zhou, F.; Ji, B.P.; Xu, J. Evaluation of combined antibacterial effects of eugenol, cinnamaldehyde, thymol, and carvacrol against E. coli with an improved method. J. Food Sci. 2009, 74, M379-M383. [CrossRef] [PubMed] 
56. De Oliveira, A.D.L.; Rodrigue, F.F.G.; Coutinho, H.D.M.; da Costa, J.G.M.; de Menezes, I.R.A. Chemical composition, modulatory bacterial resistance and antimicrobial activity of essential oil the Hyptis martiusii benth. by direct and gaseous contact. Jundishapur J. Nat. Pharm. Prod. 2014, 9, e13521. [CrossRef]

57. Oliva, A.; Costantini, S.; de Angelis, M.; Garzoli, S.; Božović, M.; Mascellino, M.T.; Vullo, V.; Ragno, R. High potency of Melaleuca alternifolia essential oil against multi-drug resistant gram-negative bacteria and methicillin-resistant Staphylococcus aureus. Molecules 2018, 23, 2584. [CrossRef]

58. Miladi, H.; Zmantar, T.; Kouidhi, B.; Chaabouni, Y.; Mahdouani, K.; Bakhrouf, A.; Chaieb, K. Use of carvacrol, thymol, and eugenol for biofilm eradication and resistance modifying susceptibility of Salmonella enterica serovar Typhimurium strains to nalidixic acid. Microb. Pathog. 2017, 104, 56-63. [CrossRef]

59. Fadli, M.; Saada, A.; Sayadi, S.; Chevalier, J.; Mezrioui, N.E.; Pagès, J.M.; Hassani, L. Antibacterial activity of Thymus maroccanus and Thymus broussonetii essential oils against nosocomial infection - bacteria and their synergistic potential with antibiotics. Phytomedicine 2012, 19, 464-471. [CrossRef]

60. Magi, G.; Marini, E.; Facinelli, B. Antimicrobial activity of essential oils and carvacrol, and synergy of carvacrol and erythromycin, against clinical, erythromycin-resistant Group A Streptococci. Front. Microbiol. 2015, 6, 165. [CrossRef]

61. Rao, H.; Lai, P.; Gao, Y. Chemical composition, antibacterial activity, and synergistic effects with conventional antibiotics and nitric oxide production inhibitory activity of essential oil from Geophila repens (L.) I.M. Johnst. Molecules 2017, 22, 1561. [CrossRef]

62. Aelenei, P.; Rimbu, C.M.; Guguianu, E.; Dimitriu, G.; Aprotosoaie, A.C.; Brebu, M.; Horhogea, C.E.; Miron, A. Coriander essential oil and linalool-interactions with antibiotics against Gram-positive and Gram-negative bacteria. Lett. Appl. Microbiol. 2019, 68, 156-164. [CrossRef]

63. Yang, S.K.; Yusoff, K.; Mai, C.W.; Lim, W.M.; Yap, W.S.; Lim, S.H.E.; Lai, K.S. Additivity vs. synergism: Investigation of the additive interaction of cinnamon bark oil and meropenem in combinatory therapy. Molecules 2017, 22, 1733. [CrossRef] [PubMed]

64. Rubini, D.; Banu, S.F.; Nisha, P.; Murugan, R.; Thamotharan, S.; Percino, M.J.; Subramani, P.; Nithyanand, P. Essential oils from unexplored aromatic plants quench biofilm formation and virulence of Methicillin resistant Staphylococcus aureus. Microb. Pathog. 2018, 122, 162-173. [CrossRef] [PubMed]

65. Koo, H.; Allan, R.N.; Howlind, R.P.; Hall-Stoodleye, L.; Stoodley, P. Targeting microbial biofilms: Current and prospective therapeutic strategies. Nat. Rev. Microbiol. 2017, 15, 740-755. [CrossRef] [PubMed]

66. Carneiro, V.A.; Santos, H.S.; Arruda, F.V.S.; Bandeira, P.N.; Albuquerque, M.R.J.R.; Pereira, M.O.; Henriques, M.; Cavada, B.S.; Teixeira, E.H. Casbane diterpene as a promising natural antimicrobial agent against biofilm-associated infections. Molecules 2011, 16, 190-201. [CrossRef]

67. Budzyńska, A.; Rożalska, S.; Sadowska, B.; Rożalska, B. Candida albicans/Staphylococcus aureus dual-species biofilm as a target for the combination of essential oils and fluconazole or mupirocin. Mycopathologia 2017, 182, 989-995. [CrossRef]

68. Kim, Y.G.; Lee, J.H.; Gwon, G.; Kim, S.I.; Park, J.G.; Lee, J. Essential oils and eugenols inhibit biofilm formation and the virulence of Escherichia coli O157:H7. Sci. Rep. 2016, 6, 36377. [CrossRef]

69. Yadav, M.K.; Chae, S.W.; Im, G.J.; Chung, J.W.; Song, J.J. Eugenol: A phyto-compound effective against methicillin-resistant and methicillin-sensitive Staphylococcus aureus clinical strain biolms. PLoS ONE 2015, 10, e0119564. [CrossRef]

70. Marchese, A.; Barbieri, R.; Coppo, E.; Orhan, I.E.; Daglia, M.; Nabavi, F.S.; Izadi, M.; Abdollahi, M.; Nabavi, S.M.; Ajami, M. Antimicrobial activity of eugenol and essential oils containing eugenol: A mechanistic viewpoint. Crit. Rev. Microbiol. 2017, 43, 668-689. [CrossRef]

71. Rathinam, P.; Viswanathan, P. Anti-virulence potential of eugenol-rich fraction of Syzygium aromaticum against multidrug resistant uropathogens isolated from catheterized patients. Avicenna J. Phytomed. 2018, 8, 416-431.

72. Ghosh, T.; Das, A.B.; Jena, B.; Pradhan, C. Antimicrobial effect of silver zinc oxide (Ag-ZnO) nanocomposite particles. Front. Life Sci. 2014, 8, 47-54. [CrossRef]

73. Mojsoska, B.; Carretero, G.; Larsen, S.; Mateiu, R.V.; Jenssen, H. Peptoids successfully inhibit the growth of gram negative E-coli causing substantial membrane damage. Sci. Rep. 2017, 14, 42332. [CrossRef] [PubMed]

74. Husain, F.M.; Ahmad, I.; Khan, M.S.; Ahmad, E.; Tahseen, Q.; Khan, M.S.; Alshabib, N.A. Sub-MICs of Mentha piperita essential oil and menthol inhibits AHL mediated quorum sensing and biofilm of Gram-negative bacteria. Front. Microbiol. 2015, 6, 420. [CrossRef] [PubMed] 
75. Poli, J.P.; Guinoiseau, E.; Serra, D.R.; Sutour, S.; Paoli, M.; Tomi, F.; Quilichini, Y.; Berti, L.; Lorenzi, V. Anti-quorum sensing activity of 12 essential oils on Chromobacterium violaceum and specific action of cis-cis- $p$-menthenolide from Corsican Mentha suaveolens ssp. Insularis. Molecules 2018, 23, 2125. [CrossRef] [PubMed]

76. Lu, L.; Hu, W.; Tian, Z.; Yuan, D.; Yi, G.; Zhou1, Y.; Cheng, Q.; Zhu1, J.; Li, M. Developing natural products as potential anti-biofilm agents. Chin. Med. 2019, 14, 11. [CrossRef]

77. Dool, H.D.; Kratz, P.D. A generalization of the retention index system including linear temperature programmed gas-liquid partition chromatography. J. Chromatogr. A 1963, 11, 463-471. [CrossRef]

78. Almeida, M.V.A.; Cangussú, Í.M.; Carvalho, A.L.S.; Brito, I.L.P.; Costa, R.A. Drug resistance, AmpC- $\beta$-lactamase and extended-spectrum $\beta$-lactamase-producing Enterobacteriaceae isolated from fish and shrimp. Rev. Inst. Med. Trop. São Paulo. 2017, 59, e70. [CrossRef]

79. CLS. Methods for Dilution Antimicrobial Susceptibility Tests for Bacteria that Grow Aerobically: Approved Standard, 10th ed.; CLSI document M07-A10; Clinical and Laboratory Standards Institute: Wayne, PA, USA, 2015.

80. Field, D.; Quigley, L.; O'Connor, P.M.; Rea, M.C.; Daly, K.; Cotter, P.D.; Hill, C.; Ross, R.P. Studies with bioengineered Nisin peptides highlight the broad-spectrum potency of Nisin V. Microb. Biotechnol. 2010, 3, 473-486. [CrossRef]

81. White, R.; Burgess, D.S.; Manduru, M.; Bosso, J.A. Comparison of three different in vitro methods of detecting synergy: Time-kill, checkerboard, and E test. Antimicrob. Ag. Chemother. 1996, 40, 1914-1918. [CrossRef]

82. European Committee for Antimicrobial Susceptibility Testing (EUCAST) of the European Society of Clinical Microbiology and Infectious Diseases. Terminology Relating to Methods for the Determination of Susceptibility of Bacteria to Antimicrobial Agents; EUCAST Definitive Document E. Def 1.2; European Committee for Antimicrobial Susceptibility Testing (EUCAST) of the European Society of Clinical Microbiology and Infectious Diseases (ESCMID): Basel, Switzerland, 2000.

Sample Availability: Samples of the compounds EOOG, Ocimum gratissimum EO, are available from the authors.

(C) 2019 by the authors. Licensee MDPI, Basel, Switzerland. This article is an open access article distributed under the terms and conditions of the Creative Commons Attribution (CC BY) license (http://creativecommons.org/licenses/by/4.0/). 